\title{
Experimental Investigation and Fabrication of an Evacuate Tube Solar Collector
}

\author{
Tushar Choudhary ${ }^{1}$, Kumar Shridhar ${ }^{2}$ \\ ${ }^{1}$ Department of Mechanical Engineering, G.L.Bajaj Institute of Technology and Management, Greater Noida, Uttar Pradesh, India \\ ${ }^{2}$ Department of Computer Science, Germany
}

\begin{abstract}
Use of renewable source of energy has now become of utmost attention. With increasing global pollution and subsequent decrement of global reserves of energy supply is a very crucial factor for environmental protection. Energy Generation from renewable sources like sun and utilization of generated one can optimize the global pollution. In this contrasts this paper presents one of the systems utilizing the solar energy to generate hot water for daily purpose and for industrial purpose. Evacuated $U$ tube solar water heating system is one of the effective methods of solar thermal energy collection systems. The experimental observation is that when the mass flow rate of water as well as the tap angle movement increases then heat transfer rate also increases. It was also observed that when the setup was fixed in north west direction the heat transfer rate increases with respect to time and in south west direction it also increases but highest value of heat transfer rate is at 2 pm and another at 3pm.
\end{abstract}

Keywords: Energy, Solar Energy, Water Heating, Mass flow rate.

\section{Introduction}

\subsection{Introduction to solar water heating system}

Solar water heating is a solar thermal technology in which the energy from the sun, is captured by absorbing medium and used to heat water for any industrial or commercial application. In India there are mainly three weather like summer, winter rainy and some places mostly winter month for long time to 7 to 8 and above or below the range temperatures so the range temperatures so the people faces crucial condition for hot water. So it heated the water up to temperature.

A solar water heating system (SWHS) utilizes the incident solar radiation and converts it in to thermal energy for heating the water to use in various applications. The solar water heating system consists of solar thermal collectors, water tanks; inter connecting pipelines and the water, which gets circulated within the solar water heating system. The two popular devices that are used for water heating are flat plate collectors (FPC) and evacuated tube collectors (ETC). In the year 2008-09, ETC has constituted more than 30\%of the total sales.

On July 1, 2009, there were 61 MNRE approved ETC suppliers and manufacturers. The arrival of evacuated tube collector has resulted in expanding the solar water heating supply chain significantly. Brunoldet al. mentioned that evacuated tube solar collector are of 3 different designswater in glass, heat pipe evacuated tube solar collector, evacuated U tube solar collector[2].

Ma L.et al reported that the heat pipe evacuated tubular solar collectors have some advantages, such as anti freezing, rapid start-up, resistance to high pressure, easy installation and maintenance etc. In practical application, maintain vacuum environment is very difficult because lots of non condensable gas will be produced in the heat pipe at the running process of the system. The thermal performance of the heat pipe will be subject to serious influence because of the accumulation of non-condensable gas. So running life of evacuated tube is restricted which is a serious short coming. Currently $U$ tube evacuated tube is used much more than heat pipe.

\subsection{Solar Energy}

Solar energy is a very large, inexhaustible source of energy. The power from the sun intercepted by the earth is approximately $1.8 \times 10^{11} \mathrm{MW}$ which is mainly thousands of times larger than the present consumption rate on earth of all commercial energy sources. Thus, in principle, solar energy could supply all the present and future needs of the world on a continuing basis.

Sun is a source of renewable energy, it is largely a sphere of hot gases. It ${ }^{\text {ee }} \mathrm{s}$ diameter is $1.39 \times 10^{6} \mathrm{~km}$ while that of earth is $1.27 \times 10^{4} \mathrm{~km}$.

\subsection{Solar Technologies}

1.3.1 Active solar technologies

1.3.2 Passive solar technologies

\subsubsection{Active solar technologies}

Active solar technologies are employed to convert solar energy into another more useful form of energy. This would normally be a conversion to heat or electrical energy. The basic benefit of active systems is that controls can be used to maximize their effectiveness. Using sensors and pumps, a relatively small amount of energy can harvest a far larger amount of available thermal energy by switching on as soon a useful temperature differential becomes present.

\subsubsection{Passive solar Technologies}

Passive solar technologies use sunlight without active mechanical systems. Such technologies convert sunlight into usable heat, cause air-movement for ventilating, or future use with little use of other energy sources. 


\section{International Journal of Science and Research (IJSR) \\ ISSN (Online): 2319-7064}

Index Copernicus Value (2013): 6.14 | Impact Factor (2014): 5.611

Passive solar technologies include direct and indirect solar gain for space heating, solar water heating systems based on geyser pumps and phase change materials.

\subsection{Advantages of Solar Collectors}

- Thermal energy can be used to passively heat buildings through the use of certain building materials and architectural design, or used directly to heat water for house hold use.

- They use solar energy which is a free renewable source of energy

- We can build our own solar water heating systems.

In the present work we use Evacuated tube solar collector heaters.

\subsection{Application of Evacuated Tube Solar Collector}

The technology is mainly employed in residential buildings where the demand for hot water is significant. This occurs when there is a large family, within laundry washing. The technology is also employed for heating the space in winter climate. Solar water heating systems are most likely to be cost effective for operations such as laundries or kitchens that demand large volume of hot water. Notable applications of evacuated U tube solar collectors are :

- In space heating

- In school, hospital

- Generally used in northern countries for heating purposes like swimming pool as per season.

\subsection{Difference between Evacuated tube and solar collector}

- Sun maxx plate collectors use a highly efficient flat absorber material called tinox which transfers heat to a series of copper tubes which circulates a $50 \%$ glycol/water mix. The collectors themselves are in essence a sealed insulated box which captures the suns energy and transfers it via the tinox, then through the pipes filled with glycol and into the storage tanks.

- Evacuated tube collectors are best used in northern climates where freezing can occur and can be utilized in areas where temperatures drop down to $-60^{\circ} \mathrm{F}$. Evacuated tubes are extremely efficient by vitue of the tubes themselves. Evacuated tubes can also be replaced if damaged, simply by plugging it in, no need to replace the whole unit.

\section{Literature Review}

\subsection{About the present work}

In literature review on the related topics is discussed. First a brief introduction of working principle of evacuated tube collector (ETC) system and advantages of the system. Solar water heater (ETC System) works on a simple principle „Black body heat absorption principle ${ }^{e}$. The principle says ,black color absorbs maximum heat, more than any other colore. Solar water heating systems using vacuum tubes made of borosilicate glass with special coating to absorb the solar energy are called ETC systems.
Air between the gaps of two glass tubes is evacuated. It results in high level of vacuum, which acts as the best insulation to minimize the heat loss from inner tube. The black coating the inner tube absorbs the solar energy and transfers it to the water.

\subsection{Thermosyphon systems}

In this type water flows through the systems and when water gets warm it rises as cooler water sinks. The principle on which this system works is called „Thermosyphon "e the key point of these systems is that: the evacuated tube solar collector is always tilted because straightness of tube would not let flow of water within the tube.

As the sun rays pass through the outer glass tubes they are largely transmitted directly to the inner glass tubes due to vacuum presence. As the inner tube surface is heated up transfer of heat to the water takes place by mans of convection inside the inner tubes.

The temperature of the water in the tubes rises making it less dense or lighter and hot and lighter water naturally moves up to the top of collector and through the evacuated collector tube goes to the outside and stored.

\subsection{REDSUN Evacuated Tube Collector Solar Water Heater Features}

- Powder coated GI stand

- Long lasting

- Vacuum jacket insulation

- Easy to install, operate and maintain

The working of evacuated solar water heater is based on a natural circulation of water within the system. The principle is called „Thermosyphon "e the key important point of these systems is that: the evacuated tube solar collector is always tilted a little because straightness of tube would not let flow of water with in the tube.

\subsection{Technical Specification of Various Elements of Evacuated U tube Solar Collector}

In this section a brief idea about the design is discussed:

Table 1: Specification and nomenclature of evacuated tube solar collector

\begin{tabular}{|c|c|c|c|}
\hline Material & Parameters & Size and other particulars & Unit \\
\hline \multirow{6}{*}{\begin{tabular}{|c} 
Outer Glass \\
tube
\end{tabular}} & Thickness & 2 & $\mathrm{Mm}$ \\
\hline & Diameter & 47 & $\mathrm{~mm}$ \\
\hline & Conductivity & 0.74 & $\mathrm{~W} / \mathrm{m} \mathrm{k}$ \\
\hline & Transmissivity & 0.92 & \\
\hline & Refractive Index & 1.474 & \\
\hline & Length & 1500 & $\mathrm{Mm}$ \\
\hline \multirow{3}{*}{$\begin{array}{c}\text { Inner Glass } \\
\text { Tube }\end{array}$} & Diameter & 37 & $\mathrm{Mm}$ \\
\hline & Thickness & 2 & $\mathrm{~mm}$ \\
\hline & Conductivity & 0.74 & $\mathrm{~W} / \mathrm{m} \mathrm{k}$ \\
\hline \multirow{3}{*}{$\begin{array}{c}\text { Copper } \\
\text { Tube }\end{array}$} & Thickness & 0.7 & $\mathrm{Mm}$ \\
\hline & Conductivity & 398 & $\mathrm{~W} / \mathrm{m} \mathrm{k}$ \\
\hline & Diameter & 8 & $\mathrm{~mm}$ \\
\hline \multirow{2}{*}{$\begin{array}{c}\text { Absorbing } \\
\text { Coating }\end{array}$} & Absorptivity & 0.92 & \\
\hline & Emissivity & 0.08 & \\
\hline
\end{tabular}




\section{International Journal of Science and Research (IJSR) \\ ISSN (Online): 2319-7064}

Index Copernicus Value (2013): 6.14 | Impact Factor (2014): 5.611

\section{Design and Fabrication}

\subsection{Design of Equipment}

\subsubsection{Evacuated Tube}

The design of evacuated tube is in $U$ shape and made up of highly resistive borosilicate glass with $\mathrm{Al}-\mathrm{N}$. Each evacuated tube consists of two glass tubes made from extremely strong borosilicate glass. It consists of two glass tubes in between a vacuum is present. The outer tube is transparent allowing lights rays to pass through minimum reflection. The inner tube is coated with a special selective coating (Al-N/Al) which features excellent solar radiation absorption and minimum reflection properties.

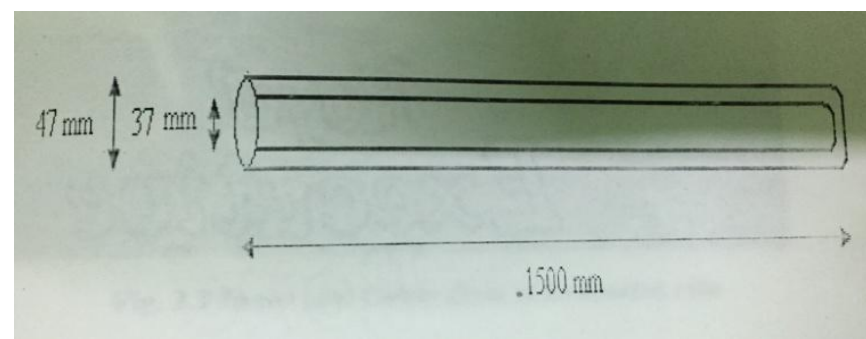

Figure 1: Evacuated tube along the length

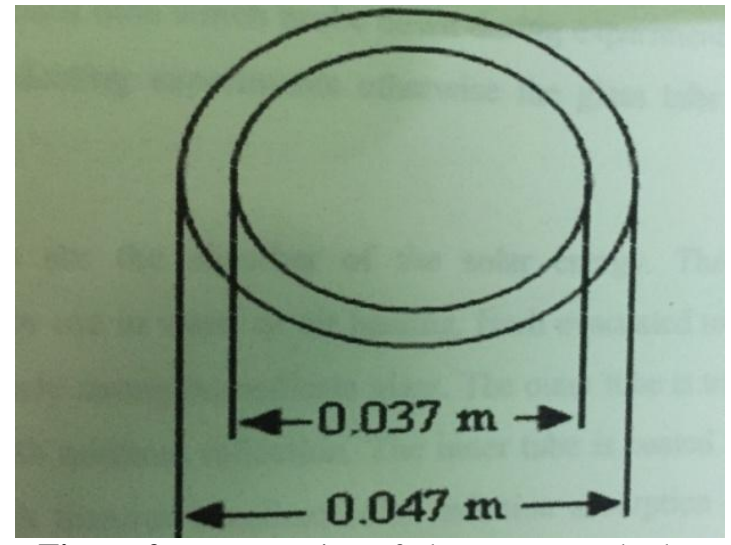

Figure 2: cross-section of glass evacuated tube

In order to maintain the vacuum between the two glass layers, a barium getter is used. During manufacture of the evacuated tube this getter is exposed to high temperatures which cause the bottom of the evacuated tube to be coated with a pure layer of barium. This barium layer actively absorbs any $\mathrm{CO}, \mathrm{CO} 2, \mathrm{~N} 2, \mathrm{O} 2, \mathrm{H} 2 \mathrm{O}$ and $\mathrm{H} 2$ out gassed from the evacuated tube during storage and operation, thus helping to maintain the vacuum. He silver colored barium layer will turn white if the vacuum is ever lost. This makes it easier to determine whether the tube is in a god condition or not.

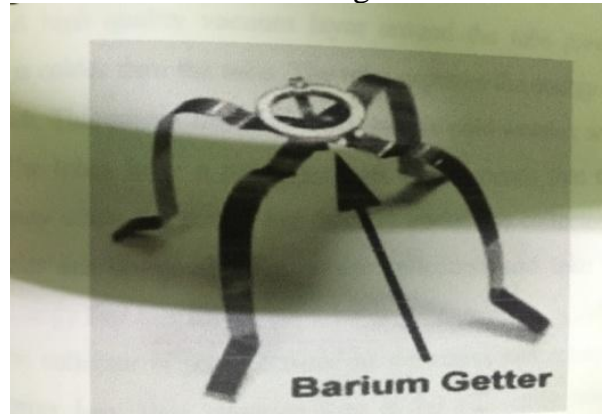

Figure 3: Getter is located at the bottom of the evacuated tube

\subsubsection{Header or Heat Exchanger}

The outer body of the header is made up of the cast iron. It consists of a square pipe which is of steel. The pipe consists of 15 holes, 15 on each side in which the evacuated tubes are placed. Open end of the evacuated tubes are in these holes and the close ends are supported by the frame. Outer the square pipe, an insulation of glass wool material is used to stop the heat transfer from the header to the atmosphere. The header consists of a hollow pipe in the center of diameter $60 \mathrm{~mm}$ through which air flows.

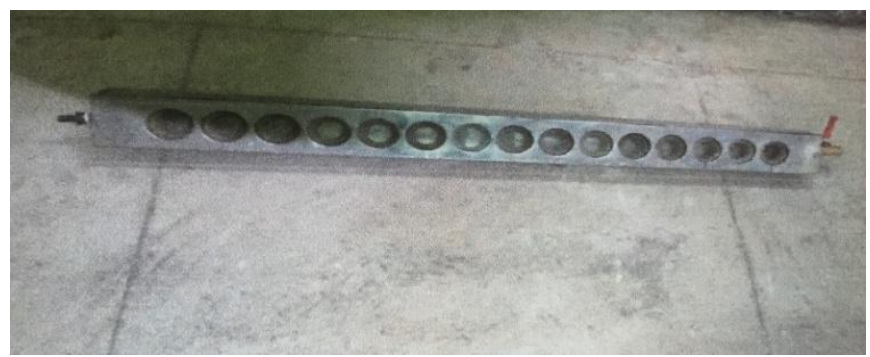

Figure 4: Header or heat exchanger

Inside the header a rectangular pipe of $1200 \mathrm{~mm}$ is inserted centrally whose one end is closed and other end is opened to which a blower is attached. On rectangular pipe at an equal distance of $70 \mathrm{~mm}$ and 15 holes are drilled on which $12 \mathrm{~mm}$ inside diameters brass nuts are welded.

\subsubsection{Frames}

The frame was made up of cast iron having slots on both the arm. Header was fitted on the front portion of frame. The frame is made rigid for conducting experiments.

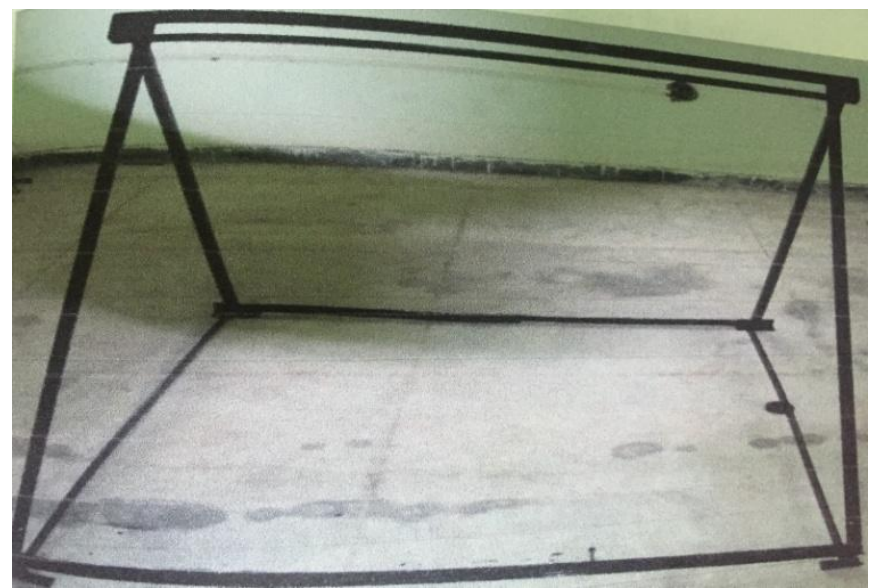

Figure 5: Testing data- load current (amperes)

\subsubsection{Pen type Thermometer}

Pen type thermometer is good for measuring water temperature and normal contract temperature testing. The meter is easy to operate. Just push out the probe cover and install the battery. Touch the object and press the ON button to measure the temperature.

\subsubsection{Other Accessories}

Some other needed accessories are:

1) Water tank

2) Inlet and Outlet Tap

3) Pipes and Stand

4) Water level measuring jar 


\section{International Journal of Science and Research (IJSR) \\ ISSN (Online): 2319-7064}

Index Copernicus Value (2013): 6.14 | Impact Factor (2014): 5.611

\subsection{Fabrication of Equipment}

The experimental setup is developed at workshop for the conduction of experiment. Special care was to be taken to prevent the leakage from the tubes and joints. The leaks were tested using the soap bubble method by pressurizing it with air first.

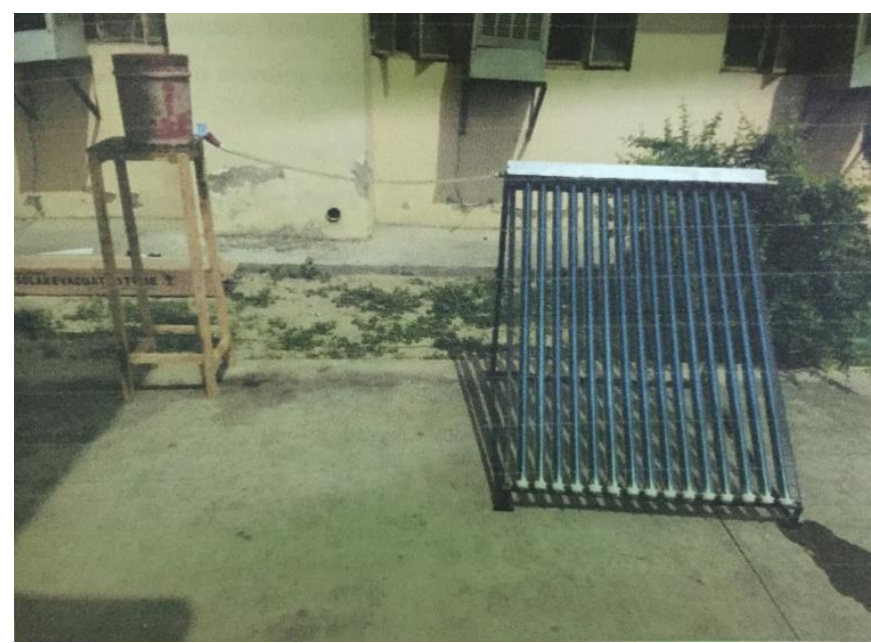

Figure 6: Experimental setup

\section{Results and Discussions}

\subsection{Experimental Results}

When the full project is ready then the readings are noted down by the measuring equipments like thermometer, beaker and the angle movement of the outlet tap. The setup was prepared to run at 8 a.m in the morning and the experiments from 9 am to $4 \mathrm{pm}$ were calculated on day by day basis.

The main nine elements as per in the table are:

1) Time: Time taken and time interval are important variables.

2) Angle: Opening of angle is directly proportional to mass flow of water because mass flow rate of water is totally dependent on the opening and closing of outlet tap.

3) Processing Time: It is time taken to fill a beaker of 250ml.

4) Mass flow rate of water (m): Mass flow of water is important constraint.

5) Inlet temperature of water (Ti): Inlet temperature of water is important constraint.

6) Outlet temperature of water (To): Outlet temperature of water is important constraint.

7) Difference between inlet and outlet temperature: The difference is calculated by noting the Inlet and Outlet temperature of water.

8) Specific heat at constant pressure (Cp): Cp depends upon the temperature of water.

9) Heat transfer rate $(\mathbf{H})$ : The heat transfer rate is calculated using the basic heat transfer relation.

\begin{tabular}{|c|c|c|c|c|c|c|c|c|}
\hline 5 & & ine & Eves & n & tab & Is: & 18 & 16 \\
\hline $900 \mathrm{AM}$ & 30 & 22 & 0.014 & 26. & 46 & 12 & 4.13 & ancess \\
\hline $900 \mathrm{AM}$ & 60 & 18 & 0.012 & 25.6 & $4 x$ & 172 & 4179 & asmus \\
\hline $900 \mathrm{MM}$ & 90 & 16 & $0.015 x$ & aes & 43 & 153 & $4 m$ & armese \\
\hline $1000 \mathrm{MM}$ & 30 & 20 & o.0125 & 306 & 4 & 134 & 4.15 & a.coses \\
\hline $1000 \mathrm{AM}$ & 60 & 16 & 0.0156 & 30.8 & 44 & 126 & 4.196 & Oasno \\
\hline $1000 \mathrm{NM}$ & 90 & 15 & 0.0167 & 308 & us & 13.7 & 4126 & essmis \\
\hline $1100, A M$ & 30 & 22 & 0.0114 & 311 & 603 & 285 & 2135 & $2.3600 \mathrm{n}$ \\
\hline $1150 \mathrm{~mm}$ & $\omega$ & 15 & 0.0167 & 31.8 & 60.4 & 286 & 2118 & 1 mon \\
\hline $1100 \mathrm{AM}$ & 90 & 10 & 0.025 & 32.4 & so. & 239 & 4.191 & 102790 \\
\hline 1200 & 30 & 28 & 0,0069 & 34 & $n_{1}$ & « & 491 & $2417 \times 6$ \\
\hline $12+\infty 0$ & 60 & 12 & 0.0208 & 342 & $n .2$ & $3 a$ & 431 & 23 tases \\
\hline $12=0$ & 90 & 10 & 0.025 & 34.2 & n.7. & 3as & 4.191 & 4.03383 \\
\hline 100 & 30 & 27 & 0,0093 & 35.1 & 10.4 & 45 & 4.195 & 1.75s600 \\
\hline 100 & 60 & 12 & 0.0208 & 35.2 & $\operatorname{sos}$ & 453 & 4.195 & 1952607 \\
\hline 100 & 90 & 10 & 0.025 & 353 & 503 & 45.6 & 4195 & 4.7es \\
\hline 200 & 30 & 21 & 00119 & 37.1 & n & 419 & 4185 & 2151503 \\
\hline 2000 & 60 & 17 & 0.0147 & 37,1 & 212 & 43 & 4197 & 2.72070 \\
\hline 200 & 90 & 13 & 0.0192 & 372 & ass & 463 & 4.197 & 2750965 \\
\hline 3.00 & 30 & If & 0.0139 & 32.5 & $n .7$ & 452 & 4.197 & 2636571 \\
\hline 3.00 & 60 & 10.5 & 0.0238 & 325 & ns & 45 & 4.197 & C.494967 \\
\hline 300 & 90 & 9 & 0.0278 & 32.3 & $n 1$ & 44.3 & $\begin{array}{l}4.97 \\
4.97\end{array}$ & $\begin{array}{l}322 \mathrm{~min} \\
1.20 \mathrm{~s}\end{array}$ \\
\hline 400 & 30 & 25 & 001 & 322 & 61 & $\begin{array}{l}258 \\
226\end{array}$ & 4.19 & 2 nems \\
\hline 400 & 60 & u & 0.0227 & 223 & $\begin{array}{l}609 \\
608\end{array}$ & $2 e s$ & 4197 & 2.20036 \\
\hline 4.00 & 90 & 10 & 0.025 & 323 & & & & \\
\hline
\end{tabular}

Figure 7: Observation table for day 1

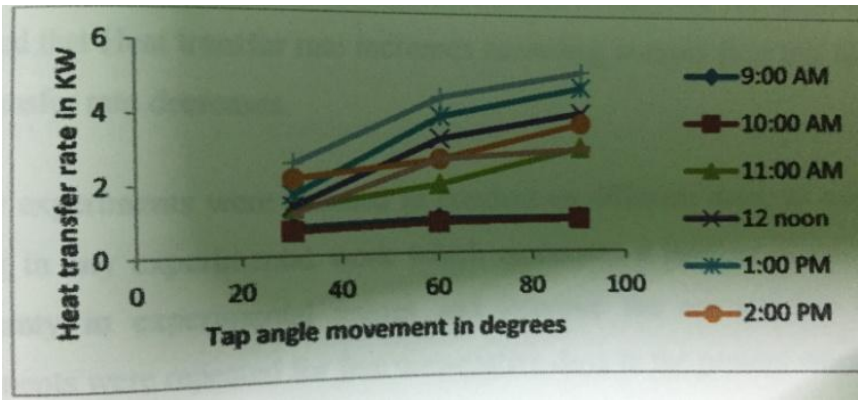

Figure 8: Experimental observation for heat transfer rate and tap angle movement for 9am-4pm(day 1)

Figure [8] shows the observations made on DAY 1 when the setup was tested for 8 hours. It was observed that when the outlet tap angles increases, the Heat Transfer rate increases. At each and every angle movement mass flow rate of water increases and heat transfer rate increases too. It was observed that the minimum flow rate was at 30 and maximum at 90 . The maximum flow rate was at $3 \mathrm{pm}$.

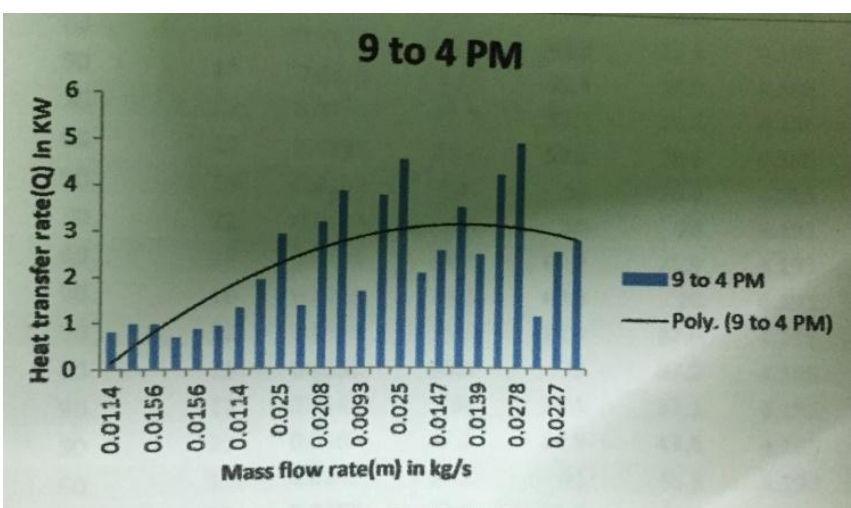

Figure 9: Experimental observation for comparison of mass flow rate and heat transfer rate for 9am - 4pm(day1) 


\section{International Journal of Science and Research (IJSR) \\ ISSN (Online): 2319-7064 \\ Index Copernicus Value (2013): 6.14 | Impact Factor (2014): 5.611}

Figure [9] shows the observations made on DAY 1 when the setup was tested for 8 hours. It was observed that heat transfer rate increases according to the mass flow rate of water but after 3 pm heat transfer rate decreases.

DAY 2:

\begin{tabular}{|c|c|c|c|c|c|c|c|c|}
\hline ine & Angle & Pro Time & $\mathrm{m}(\mathrm{kg} / \mathrm{s})$ & $\pi$ & To & To-1I & $C_{p}$ & $Q(k w)$ \\
\hline $9: 00 \mathrm{AM}$ & 30 & 22 & 0.0114 & 27.5 & 41.2 & 13.7 & 4.179 & 0.652676 \\
\hline $9: 00 \mathrm{AM}$ & 60 & 17 & 0.0147 & 27.6 & 41.3 & 13.7 & 4.179 & 0.841609 \\
\hline $9: 00 \mathrm{AM}$ & 90 & 15 & 0.0167 & 27.9 & 41.6 & 13.7 & 4.179 & 0.956113 \\
\hline 10:00 AM & 30 & 21 & 0.0119 & 29.2 & 43 & 13.8 & 4.179 & 0.686275 \\
\hline $10: 00 \mathrm{AM}$ & 60 & 18 & 0.0139 & 29.3 & 43.2 & 13.9 & 4.186 & 0.808777 \\
\hline $10: 00 \mathrm{AM}$ & 90 & 14 & 0.0179 & 29.7 & 43.4 & 14.2 & 4.186 & 1.063997 \\
\hline $11: 00$ АМ & 30 & 23 & 0.0109 & 31.1 & 57.7 & 26.6 & 4.186 & 1.213689 \\
\hline $11: 00 \mathrm{AM}$ & 60 & 19 & 0.0132 & 31.3 & 57.9 & 26.6 & 4.186 & 1.469788 \\
\hline $11: 00 \mathrm{AM}$ & 90 & 15 & 0.0167 & 31.4 & 58 & 26.6 & 4.191 & 1.861726 \\
\hline 12:00 & 30 & 21 & 0.0119 & 34 & 60 & 26 & 4.191 & 1.296695 \\
\hline 12:00 & 60 & 18 & 0.0139 & 34.1 & 60.2 & 25.9 & 4.191 & 1.508802 \\
\hline 12:00 & 90 & 16 & 0.0156 & 34.3 & 60.3 & 26 & 4.191 & 1.699869 \\
\hline 1:00 & 30 & 22 & 0.0114 & 35.6 & 72.9 & 37.6 & 4.195 & 1.798145 \\
\hline 1:00 & 60 & 19 & 0.0132 & 35.8 & 73 & 37.2 & 4.195 & 2.059913 \\
\hline 1:00 & 90 & 17 & 0.0147 & 36 & 73.1 & 37.1 & 4.195 & 2.287227 \\
\hline 2:00 & 30 & 23 & 0.0109 & 37.1 & 80.9 & 43.8 & 4.195 & 2.002777 \\
\hline 2:00 & 60 & 17 & 0.0147 & 37.2 & 81 & 43.8 & 4.197 & 2.70228 \\
\hline 2:00 & 90 & 15 & 0.0167 & 37.4 & 81.2 & 43.8 & 4.197 & 3.069938 \\
\hline $3: 00$ & 30 & 20 & 0.0125 & 35.1 & 77.1 & 42 & 4.197 & 2.203425 \\
\hline 3:00 & 60 & 18 & 0.0139 & 35 & 77 & 42 & 4.197 & 2.450209 \\
\hline 3:00 & 90 & 15 & 0.0167 & 35 & 77 & 42 & 4.197 & 2.943776 \\
\hline 4:00 & 30 & 22 & 0.0114 & 33 & 60.8 & 27.8 & 4.197 & 1.330113 \\
\hline $4: 00$ & 60 & 19 & 0.0132 & 32.9 & 604 & 27.6 & 4.197 & 1.529051 \\
\hline 4:00 & 90 & 16 & 0.0156 & 32.8 & 60.4 & 27.6 & 4.197 & 1.80706 \\
\hline
\end{tabular}

Figure 10: Observation table for day 2

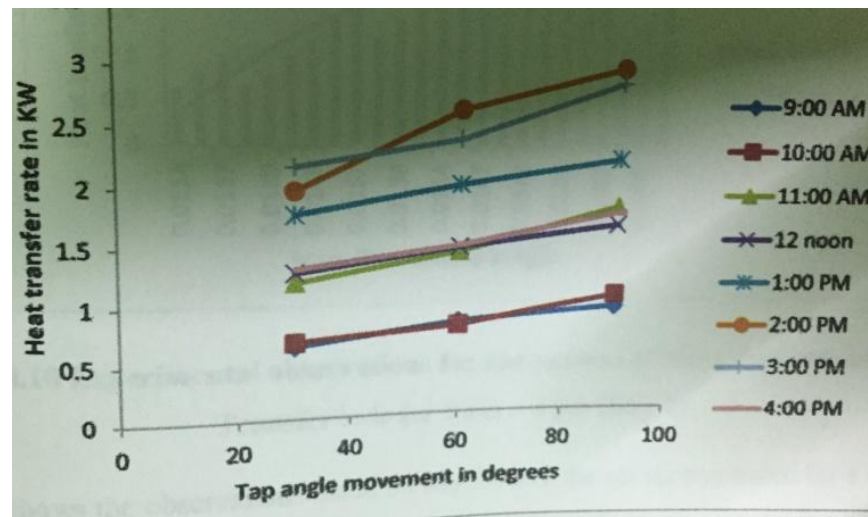

Figure 10: Experimental observation for comparison of mass flow rate and heat transfer rate for 9am - 4pm(day2)

Figure shows the observations made on DAY 2 when the setup was tested for 8 hours. It was observed that when the tap angles increases, the Heat Transfer rate increases. It was observed that the maximum flow rate was at $2 \mathrm{pm}$ and minimum Heat transfer rate at 9 am.

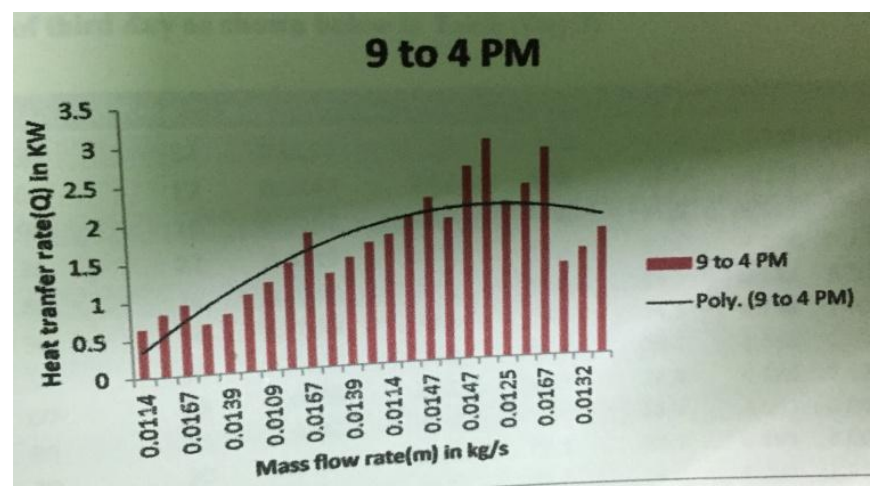

Figure 11: Experimental observation for comparison of mass flow rate and heat transfer rate for 9am - 4pm(day2)

Figure [11]: shows the observations made on DAY 2 when the setup was tested for 8 hours. It was observed that heat transfer rate increases according to the mass flow rate of water but after 2 pm heat transfer rate decreases.

\section{DAY 3:}

\begin{tabular}{|c|c|c|c|c|c|c|c|c|}
\hline Time & Angle & Pro Time & $\mathrm{m}(\mathrm{kg} / \mathrm{s})$ & $\mathrm{Ti}$ & To & To-TI & $C_{p}$ & $\mathrm{Q}(\mathrm{KW})$ \\
\hline 9:00 AM & 30 & 22 & 0.0114 & 28 & 43.5 & 15.5 & 4.179 & 0.738429 \\
\hline $9: 00 \mathrm{AM}$ & 60 & 17 & 0.0147 & 28.1 & 43.7 & 15.6 & 4.179 & 0.958328 \\
\hline 9:00 AM & 90 & 15 & 0.0167 & 28.3 & 43.8 & 15.5 & 4.179 & 1.081734 \\
\hline $10: 00 \mathrm{AM}$ & 30 & 21 & 0.0119 & 30.1 & 44.7 & 14.6 & 4.179 & 0.726059 \\
\hline 10:00 AM & 60 & 16 & 0.0156 & 30.2 & 44.9 & 14.7 & 4.186 & 0.959934 \\
\hline $10: 00 \mathrm{AM}$ & 90 & 14 & 0.0179 & 30.5 & 45 & 14.5 & 4.186 & 1.086476 \\
\hline 11:00 AM & 30 & 23 & 0.0109 & 32 & 60.7 & 28.7 & 4.186 & 1.309506 \\
\hline 11:00 AM & 60 & 18 & 0.0139 & 32.1 & 60.9 & 28.8 & 4.186 & 1.675739 \\
\hline $11: 00 \mathrm{AM}$ & 90 & 15 & 0.0167 & 32.3 & 61 & 28.7 & 4.191 & 2.008704 \\
\hline $12: 00$ & 30 & 20 & 0.0125 & 34.2 & 72.5 & 38.3 & 4.191 & 2.006441 \\
\hline $12: 00$ & 60 & 18 & 0.0139 & 34.3 & 72.7 & 38.4 & 4.191 & 2.236988 \\
\hline $12: 00$ & 90 & 17 & 0.0147 & 34.4 & 72.7 & 38.3 & 4.191 & 2.359575 \\
\hline $1: 00$ & 30 & 22 & 0.0114 & 35.5 & 74 & 38.5 & 4.195 & 1.841186 \\
\hline $1: 00$ & 60 & 19 & 0.0132 & 35.6 & 74.2 & 38.6 & 4.195 & 2.137436 \\
\hline 1:00 & 90 & 14 & 0.0179 & 35.8 & 74.5 & 38.7 & 4.195 & 2.906002 \\
\hline 2:00 & 30 & 23 & 0.0109 & 37.4 & 82 & 44.6 & 4.195 & 2.039357 \\
\hline $2: 00$ & 60 & 18 & 0.0139 & 37.5 & 82.5 & 45 & 4.197 & 2.625223 \\
\hline $2: 00$ & 90 & 15 & 0.0167 & 37.7 & 82.7 & 45 & 4.197 & 3.154046 \\
\hline $3: 00$ & 30 & 21 & 0.0119 & 32.7 & 77.5 & 44.8 & 4.197 & 2.237505 \\
\hline 3:00 & 60 & 17 & 0.0147 & 32.5 & 77.4 & 44.8 & 4.197 & 2.763976 \\
\hline 3:00 & 90 & 15 & 0.0167 & 32.4 & 77.2 & 44.8 & 4.197 & 3.140027 \\
\hline $4: 00$ & 30 & 23 & 0.0109 & 30.5 & 60.8 & 30.3 & 4.197 & 1.386143 \\
\hline 4:00 & 60 & 19 & 0.0132 & 30.3 & 60.5 & 30.2 & 4.197 & 1.673092 \\
\hline $4: 00$ & 90 & 15 & 0.0167 & 30 & 60.4 & 30.4 & 4.197 & 2.130733 \\
\hline
\end{tabular}

Figure 12: Observation table for day 3

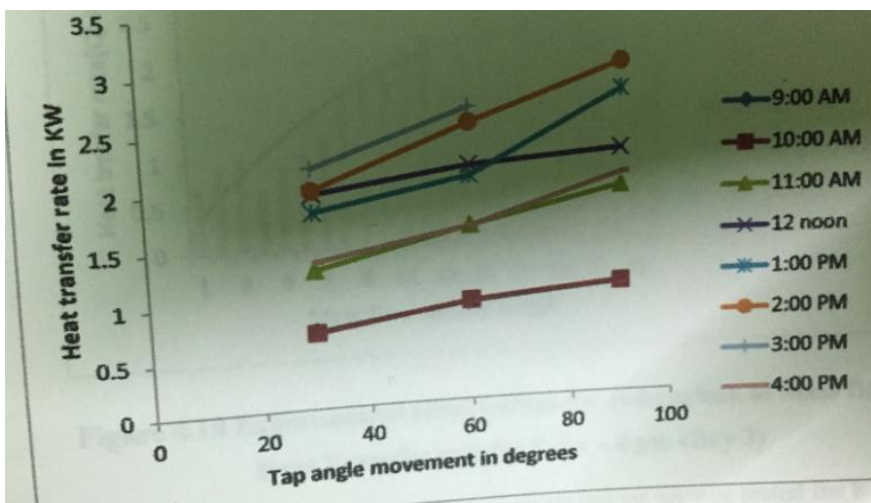

Figure13: Experimental observation for comparison of mass flow rate and heat transfer rate for 9am - 4pm(day3)

Figure [13]: shows the observations made on DAY 3 when the setup was tested for 8 hours. It was observed that when the tap angles increases, the Heat Transfer rate increases. It was observed that the maximum flow rate was at $3 \mathrm{pm}$ and minimum Heat transfer rate at 9 am. 


\section{International Journal of Science and Research (IJSR) ISSN (Online): 2319-7064 \\ Index Copernicus Value (2013): 6.14 | Impact Factor (2014): 5.611}

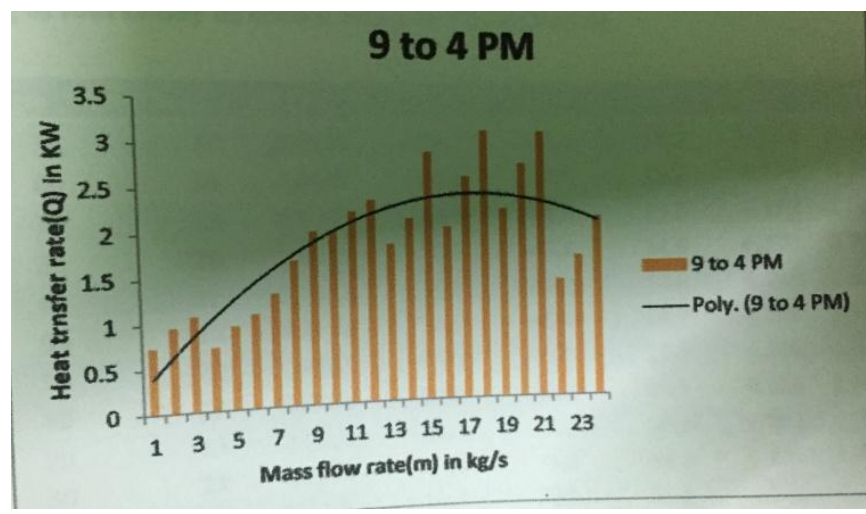

Figure 14: Experimental observation for comparison of mass flow rate and heat transfer rate for 9am - 4pm(day3)

Figure [14]: shows the observations made on DAY 3 when the setup was tested for 8 hours. It was observed that heat transfer rate increases according to the mass flow rate of water but after 2 pm heat transfer rate decreases.

\subsection{Calculations}

$\mathbf{Q}=\mathbf{m} * \mathbf{C} \mathbf{p} *(\mathbf{T o}-\mathbf{T i})$

Where,

$\mathrm{m}=$ Mass flow rate in $\mathrm{kg} / \mathrm{s}$

$\mathrm{Q}=$ Heat Transfer rate in $\mathrm{KW}$

$\mathrm{Cp}=$ Specific Heat at constant pressure in $\mathrm{kJ} / \mathrm{kg} \mathrm{k}$

To $=$ Outlet temperature in degree Celsius

$\mathrm{Ti}=$ Inlet temperature in degree Celsius

\section{Conclusion and Future Scope}

\subsection{Conclusion}

From the experiment and research, it is clear that the evacuated tube solar collector possess 25\% - 40\% more efficiency than flat plate solar collector under same working conditions. Also, the cylindrical fin provides more efficiency than any other shape of absorber fin.

After concluding the experiments following conclusions were found:

1) The heat transfer rate increases first and then decreases from morning to evening, having its peak value at $2 \mathrm{pm}$ in afternoon at 82 degree Celsius to 84 degree Celsius.

2) The project setup was fixed in South West direction at DAY 1. The temperature was maximum at $2 \mathrm{pm}$ but the heat transfer was maximum at $3 \mathrm{pm}$.

3) The project setup was fixed in North West direction at DAY 2. The temperature and heat transfer was maximum at $2 \mathrm{pm}$.

4) The project setup was fixed in south west direction at DAY 1. The temperature was maximum at $2 \mathrm{pm}$ and the heat transfer was comparable at $2 \mathrm{pm}$ and at $3 \mathrm{pm}$.

5) In total one can predict that the setup performed best around $2-3 \mathrm{pm}$ in terms of performance output.

\subsection{Future Scope}

The experimental setup performed extremely well in summers but it could not be performed in winters due to its fabrication stage. The following modifications may be done to obtain good results in future:

1) The setup may be modified to follow the sun "s movement using electronic circuitry.

2) If three to four setups are combined together, the setup can produce a large amount of hot water.

3) The reflector plate can be used for getting far better efficiency.

4) It can be used in power plant for pre heating the feed water.

\section{References}

[1] Rabl, A,J O'Gallagher, and R. Winston. "Design and test of non evacuated solar collectors with compound parabolic concentrators." Solar energy 25.4(1980:335351).

[2] Solar Energy Fundamental and application by H. P. Grag

[3] Z.D.Cheng, Y.L.He, J.Xiao, Y.B.Tao, R.J.Xu, “Threedimensional numerical study of heat transfer characteristics in the receiver tube of parabolic trough solar collector", International Communications in Heat and Mass Transfer, vol.37, pp.782-787, 2010

[4] E.Azad, "Theoretical and experimental investigation of heat pipe solar collector", Experimental Thermal Fluid Sciences, vol.32, pp.1666-1672, 2008

[5] P.Selvakumar, S.A.Prasanth, N.Rakesh, A.Vignesh, "Fluid flow and heat transfer analysis on multiple parabolic trough collectors by varying heat transfer fluids", Undergraduate Project Thesis, India: Anna University of Technology Coimbatore, 2011

[6] X.R.Zhang, H.Yamaguchi, "An experimental study on evacuated tube solar collector using supercritical CO2 ", Applied Thermal Engineering, vol.28, pp.1225-1233, 2008.

[7] I.Budihardjo, G.L.Morrison , "Performance of waterin-glass evacuated tube solar water heaters", Solar Energy, vol.83,pp. 49-56, 2009.

[8] G.L. Morrison (2005), ,Measurement and simulation of flow rate in a water-in-glass evacuated tube solar water heatere, Solar Energy Vol. 78, pp 257-267.

[9] N.N.Wadaskar, S.R.Karale, "Experimental investigation of vacuum tube solar collector .ICETET 2009 P 1052-1057 Nagpur India..

[10] Design and study on small solar energy photovoltaic hot water system. Wuhan, China Mar 25-28, 2011 Asia pacific power and energy conference. Shaun $\mathrm{Mu}$, Dianhua Wang, Xin Guan

[11] S.J.Kline, "The purpose of uncertainty analysis", ASME Journal of Fluids Engineering, vol.117, pp.153160, 1985.

\section{Author Profile}

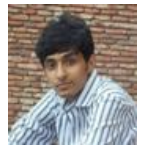

Tushar choudhary is in his final year pursuing Mechanical Engineering from D.R A.P.J Abdul kalam technical university(formerly UPTU). He is proficient in robot studio6.01. He completed his internship under APS GmbH European centre for mechatronics, Aachen, Germany and successfully executed Several industrial projects. He visions to be an entrepreneur and start an automation company which can provide quality jobs and efficient workspace. He is planning to pursue masters in germany this winter semester. 


\section{International Journal of Science and Research (IJSR) \\ ISSN (Online): 2319-7064}

Index Copernicus Value (2013): 6.14 | Impact Factor (2014): 5.611

Kumar Shridhar received his Bachelors degree in Computer Science from India in 2015 and is currently pursuing his Masters degree in Germany. His endeavor lies in his belief to make the world a better place. He is also the co-founder of uliveeasy.com. Apart from his interest in sustainable energy usage, his keen interest lies in artificial intelligence and information security, in which he is continuing his research work. 